\section{Demografiske endringer i utviklingsland}

U-landsmedisin er tradisjonelt forbundet med infeksjonssykdommer, som har utgjort den største årsaken til mortalitet og morbiditet i mange land (1). Dette bildet vil trolig endre seg, blant annet som resultat av bedret infeksjonsbehandling Dermed vil sykdomsbyrden i større grad bli preget av ikke-smittsomme lidelser som diabetes, kardiovaskulær sykdom og kreft, slik det er i høyinntektsland. Det endrede sykdomspanoramaet må ses i sammenheng med to demografiske endringer, nemlig urbanisering (2) og økende gjennomsnittsalder (3).

Epidemiologiske prognoser tilsier at nærmest all global befolkningsvekst i de kommende år vil finne sted $\mathrm{i}$ urbane strøk i lavinntekts- og middelsinntektsland. En betydelig andel av tilveksten i byene vil skje i slumområdene, med de helseproblemer dårlige sanitære forhold og manglende infrastruktur medfører. For den delen av befolkningen som klarer seg bedre økonomisk, vil imidlertid urbaniseringen medføre at stadig flere tilegner seg en såkalt vestlig livsstil, med mindre mosjon og et mer kaloriholdig kosthold, hvilket vil gi økt forekomst av f.eks. overvekt og hypertensjon (2).

Eldrebølgen antas ofte kun å angå industrialiserte land, men den demografiske transisjonen fra høye fødselsrater og kort levetid til lav spedbarnsdødelighet, lang levetid og lave fødselsrater vil trolig gå betydelig raskere i resten av verden enn den gjorde i Europa og Nord-Amerika (3). Dette gir en rask økning i gjennomsnittsalder. En indikator på alderssammensetning er andelen av befolkningen over 65 år. Tiden det tok i Frankrike for en $ø$ kning av denne andelen fra $7 \%$ i 1865 til $14 \%$ i 1979 er betydelig lengre enn de 17 årene man antar at Syria og Vietnam vil bruke på tilsvarende dobling av prosentandel av befolkningen over 65 år.

Med en eldre, mer urban befolkning må $i$ helsevesenet $i$ utviklingsland være forberedt på å behandle flere tilfeller av de tilstandene som dominerer $\mathrm{i}$ industrialiserte land.

\section{Kristoffer Brodwall}

kristoffer.brodwall@gmail.com

Barneavdelinga

Ålesund sjukehus

\section{Litteratur}

1. WHO. The global burden of disease: 2004 update. Genève: WHO, 2008: 7-26. whqlibdoc.who.int/publications/2008/ 9789241563710 eng.pdf (3.9.2009).

2. Patel RB, Burke TF. Urbanization - an emerging humanitarian disaster. N Eng J Med 2009; 361: 741-3.

3. Pison $\mathrm{G}$. Population ageing will be faster in the South than in the North. Popul Soc (Paris) 2009; 457: 1-4.

\title{
Proteinrik ferdigmat til underernærte barn
}

\author{
Proteinrik ferdigmat kan gi drastisk redusert barnedødelighet \\ i fattige og utsatte befolkninger.
}

I en intervensjonsstudie i Maradi i Niger i 2006 evaluerte man hjemmebehandling av både moderat og alvorlig akutt underernærte barn (1). De som hadde tilleggssykdommer og komplikasjoner til underernæringen, ble innlagt for stabilisering, men de fleste gikk til poliklinisk oppfølging en gang i uken. De fikk med seg pakker med energitett og proteinrik mat, såkalt RUTF (ready to use therapeutic food), for en ukeén pakke til hver dag. Energiverdien per pakke var $1000 \mathrm{kcal}$, og maten var tilsatt vitaminer og mineraler - kort sagt mange kalorier på lite volum (for små mager), maten er rik på proteiner og kan spises rett fra pakken. Det trengs ingen koking eller annen tilberedning, og maten er holdbar ved romtemperatur.

I alt ble 64733 akutt underernærte barn behandlet. Av disse var 92,5\% moderat akutt underernært (70-80\% av median vekt for høyde). Resultatene for denne gruppen var overraskende gode: Dødeligheten $(0,4 \%)$ var langt lavere, vektøkningen $(5,28 \mathrm{~g} / \mathrm{kg} / \mathrm{dag})$ langt raskere og frafallet $(3,4 \%)$ mindre enn ved tradisjonelle ernæringsprogrammer hvor barna blir innlagt $i$ ernæringssentre og gis mais-soyablanding. Den høye etterlevelsen indikerer at mødrene både hadde tro på behandlingen og syntes den var lett å følge opp. Ved hjemmebehandling kan man også behandle mange flere barn med de samme personellresursene.

For de 7,5\% av barna som var alvorlig akutt underernært (under $70 \%$ av median vekt for høyde), var dødeligheten 3,0\% og frafallet 10,3\%. Alvorlig akutt underernæring er langt vanskeligere å behandle enn moderat akutt underernæring og innebærer langt høyere relativ risiko for død. Likevel gjør det store antallet moderat underernærte barn at denne gruppen bidrar mest til den totale barnedødeligheten $\mathrm{i}$ befolkningen.

Det viktigste resultatet var imidlertid at man ikke fikk den økningen i antall barn med alvorlig akutt underernæring som man vanligvis får i løpet av det årlige «hunger gap», perioden med tømte matvarelagre før innhøsting. Antallet barn med moderat akutt underernæring økte kraftig i denne perioden, som i tidligere år, men antallet med alvorlig akutt underernæring forble lavt gjennom hele perioden. Dette kan indikere at RUTF-pakkene forebygde alvorlig akutt underernæring - som gir svært høy dødelighet - og dermed holdt den totale barnedødeligheten nede.

I en annen studie gjort i samme område ønsket man å se på om utdeling av RUTFpakker på $500 \mathrm{kcal}$ per dag også til velernærte barn (over $80 \%$ av median vekt for høyde) kunne redusere forekomsten av akutt underernæring (2). Intervensjonen besto i å gi mattilskudd til velernærte barn i alderen 6 md. -3 år. 3533 barn deltok. Både $\mathrm{i}$ intervensjonslandsbyene og $\mathrm{i}$ kontrollandsbyene fikk underernærte barn (under $80 \%$ av median vekt for høyde) mattilskudd. Ny opptreden av underernæring blant de velernærte barna var kraftig redusert $\mathrm{i}$ intervensjonsgruppen i forhold til i kontrollgruppen. Man observerte $36 \%$ reduksjon $\mathrm{i}$ insidens av total akutt underernæring og $58 \%$ reduksjon i insidens av alvorlig akutt underernæring hos velernærte barn som fikk RUTF-pakker i forhold til tilstanden hos de velernærte som ikke fikk. 23 barn døde i løpet av studien, sju i intervensjonslandsbyene og 16 i kontrollandsbyene. Dette ga ikke statistisk signifikant forskjell i dødelighet.

\section{$\emptyset$ yunn Holen}

oeyhole@online.no

Medisinsk avdeling

Oslo universitetssykehus Ullevål

Oppgitte interessekonflikter: Ingen

\section{Litteratur \\ . Defourny I, Seroux G, Abdelkader I et al. Manage- ment of moderate acute malnutrition with RUTF in Niger. Field Exchange 2007; nr. 31: 2-4. doc- torswithoutborders.org/news/malnutrition/ Management \%20 of \%20Moderate \%20Acute \%20 Malnutrition \%20with \%20RUTF \%20in \%20Niger. pdf (14.8.2009) \\ 2. Isanaka S, Nombella N, Djibo A et al. Effect of pre ventive supplementation with ready-to-use thera- peutic food on the nutritional status, mortality, and morbidity of children aged 6 to 60 months in Niger. JAMA 2009; 301: 277-85.}

